\title{
MAKNA TRADISI MEMUJA TAHON DAN BALIT BAGI UMAT BUDDHA DUSUN BARU MURMAS DESA BENTEK KECAMATAN GANGGA KABUPATEN LOMBOK UTARA
}

\author{
Putradi \\ STAB Negeri Raden Wijaya \\ putradi@gmail.com
}

\begin{abstract}
ABSTRAK
Penelitian ini bertujuan untuk mengetahui makna dan nilai-nilai yang terkandung dalam tradisi memuja Tahon dan Balit di Dusun Baru Murmas Desa Bentek Kecamatan Gangga Kabupaten Lombok Utara. Metode penelitian yang digunakan adalah studi kualitatif yang berupaya memberikan gambaran-gambaran mengenai tradisi memuja Tahon dan Balit secara natural. Tempat penelitian dilakukan di Dusun Baru Murmas Desa Bentek Kecamatan Gangga Kabupaten Lombok Utara. Objek dari penelitian adalah tradisi memuja Tahon dan Balit yang dilaksanakan oleh masyarakat Baru Murmas.Teknik pengumpulan data dengan menggunkan teknik observasi, wawancaran dan dukomentasi. Teknik analisis data menggunakan teknik trianggulasi.Hasil penelitian ini adalah: (1) Makna tradisi memuja Tahon dan Balit adalah untuk mengingat leluhur, menjaga kehidupan yang seimbang dan selaras antar manusia, alam dan leluhur dengan cara membersihkan memberikan penghormatan kepada leluhur yang menjaga masyarakat dari segala penyakit, bencana dan musibah, serta sebagai ungkapan rasa syukur masyarakat kepada leluhur atas rezeki, keselamatan dan terhindar dari penyakit. (2) Tradisi memuja Tahon dan Balit memuat nilai-nilai yang sangat lekat dengan kehidupan masyarakat di Dusun Baru Murmas. Nilai-nilai tersebut diantaranya gotong royong, persatuan dan kesatuan, musyawarah, pengendalian sosial, dan kearifan lokal. Selain nilai-nilai diatas terdapat nilai-nilai ajaran Buddha yang terkandung dalam tradisi memuja Tahon dan Balit.

Kata kunci: Tahon dan Balit, makna dan nilai-nilai
\end{abstract}

\begin{abstract}
This study aims to determine the meaning and values contained in the tradition of worshiping Tahon and Balit in Baru Murmas Hamlet, Bentek Village, Gangga District, North Lombok Regency. The research method used is a qualitative study that seeks to provide an overview of the tradition of worshiping Tahon and Balit naturally. The research site was conducted in Baru Murmas Hamlet, Bentek Village, Gangga District, North Lombok Regency. The object of the research is the tradition of worshiping Tahon and Balit which is carried out by the New Murmas community. Data collection techniques are using observation, interview and documentation techniques. Data analysis techniques using triangulation techniques. The results of this study are: (1) The meaning of the tradition of worshiping Tahon and Balit is to remember ancestors, maintain a balanced and harmonious life between humans, nature and ancestors by cleaning up paying homage to the ancestors who guarded the community from all illness, disaster and disaster, as well as an expression of gratitude to the ancestors for their fortune, safety and avoiding disease. (2) The tradition of worshiping Tahon and Balit contains values that are very closely related to community life in Baru Murmas Hamlet. These values include mutual cooperation, unity and unity, deliberation, social control, and local wisdom. In addition to the above values, there are Buddhist teachings contained in the tradition of worshiping Tahon and Balit.
\end{abstract}

Keywords: Tahon and Balit, meaning and values 


\section{PENDAHULUAN}

Masyarakat merupakan sejumlah manusia dalam arti seluas-luasnya dan terikat oleh suatu kebudayaan yang mereka anggap sama (Tim 2008: 885). Masyarakat sendiri bersifat dinamis, selalu bergerak kearah perubahan. Perubahan tersebut dapat berdampak besar yang melibatkan aspek-aspek sosial yang vital dalam masyarakat ataupun hanya berpengaruh kecil dan tidak mengubah tatanan dasar masyarakat. Sifat dinamisnya suatu masyarakat dapat berkembang dan sangat mungkin untuk mengalami perubahan.

Salah satu perubahan yang masih mempengaruhi sebagian besar masyarakat adalah modernisasi. Smith dalam (Suratman, dkk, 2010: 121) modernisasi merupakan proses yang dilandasi dengan seperangkat rencana dan kebijaksanaan yang disadari untuk mengubah masyarakat kearah kehidupan masyarakat yang kontemporer yang menurut penilaian lebih maju dalam derajat kehormatan tertentu. Pemikiran modernisasi meliputi gagasan bahwa tujuan mementingkan pengetahuan, sebagaimana dikatakan Giddens dalam (Jones 2003: 38). Sedangkan ciri-ciri modernisasi antara lain adalah kemajuan teknologi dan industrialisasi, individualisasi, sekularisasi, diferensiasi, dan akulturasi.

Sistem terbuka dunia memudahkan masyarakat saling berinteraksi dan bersentuhan dengan budaya asing sehingga timbul akulturasi. Masyarakat modern mekanisme masyarakatnya menuju kearah prinsip logika ekonomi serta orientasi kebendaan yang berlebihan dan kehidupan seseorang perhatian religiusnya dicurahkan untuk bekerja dan menumpuk kekayaan (Suratman, dkk, 2010:122-123). Persaingan yang cendrung dipicu oleh modernisasi, khususnya dalam bidang ekonomi sehingga membuat masyarakat berlomba untuk tetap bertahan dalam kehidupan mereka. Untuk dapat bertahan, pilihan yang berguna dan efisien merupakan prioritas utama. Sehingga ketika ada hal-hal yang dianggap kurang sesuai dengan perkembangan jaman tidak dianggap penting lagi. Persaingan kebutuhan membuat masyarakat menjadi praktis. Prioritas kebutuhan dan gaya hidup telah mengikis nilai-nilai budaya yang sebenarnya telah dijalani secara turuntemurun oleh nenek moyang masyarakat.

Salah satu masyarakat yang masih memilih untuk mempertahankan warisan budaya adalah masyarakat Dusun Baru Murmas Desa Bentek Kecamatan Gangga Kabupaten Lombok Utara Nusa Tenggara Barat (NTB). Masyarakat menganggap budaya tersebut merupakan kebiasan yang harus dipertahankan meskipun mengalami tantangan internal maupun eksternal. Dusun Baru Murmas merupakan suatu daerah yang berada di Selatan Desa 
Gondang dan diapit oleh dua bukit. Masyarakat yang tinggal di Dusun Baru Murmas lebih kurang 173 kepala keluarga. Mata pencaharaian dari masyarakat Dusun Baru Murmas sebagian besar adalah petani dan buruh tani. Masyarakat Dusun Baru Murmas masih menghormati salah satu bentuk kebudayaan yang dimiliki yaitu tradisi Memuja Tahon dan Balit. Masyarakat khususnya yang berada di Baru Murmas Desa Bentek Kecamatan Gangga Kabupaten Lombok Utara masih menjalankan tradisi memuja Tahon dan Balit.

Tradisi memuja Tahon dilaksanakan pada bulan April (musin hujan) dan memuja Balit dilaksanakan pada bulan Agustus (musim kemarau). Memuja Tahon dilaksankan untuk memohon rezeki atau hasil panen yang melimpah atas tanaman yang ditanam. Memuja Balit dilaksanakan sebagai rasa syukur atas rezeki atau hasil panen yang didapat masyarakat. Pelaksanaan memuja Tahon dan Balit melibatkan masyarakat dari tiga wilayah. Tiga wilayah tersebut yaitu Baru Murmas, Satan dan Karang Penasan. Masyarakat Baru Murmas, Satan dan Karang Penasan berkumpul pada saat pelaksanaan tradisi memuja Tahon dan Balit. Tiga wilayah ini saling berinteraksi karena adanya sistem adat istiadat memuja Tahon dan Balit yang mereka laksanakan.
Pelaksanaan tradisi memuja Tahon dan Balit selalu ada sesajen yang dipersembahkan untuk leluhur. Sesajen yang dipersembahkan beranekaragam jenisnya seperti: pisang, belayak, pesat menisan, lekoq buak (daun sirih dan buah pinang), nasi, sate, lauk pauk, buah-buahan serta barang-barang lainnya. Selain sesajen terdapat benda pusaka. Benda pusaka merupakan peninggalan nenek moyang yang masih disimpan dengan baik. Benda pusaka yang masih ada seperti: keris, tulub (tombak), kekepet (kipas), kulem (tongkat dan perisai), guci dan lain sebagainya. Disamping adanya benda pusaka ada ritual tari, menggerok (tari berantai) dan perang ketopat.

Masyarakat Baru Murmas sangat memegang teguh tradisi memuja Tahon dan Balit. Dapat dilihat dari antusias masyarakat dalam merayakan tradisi memuja Tahon dan Balit. Tradisi memuja Tahon dan Balit merupakan suatu keyakinan masyarakat Baru Murmas sebelum mengenal agama. Masyarakat Baru Murmas merupakan pemeluk agama Buddha. Agama Buddha masuk ke Baru Murmas tahun 70-an. Meski masyarakat Baru Murmas sudah meyakini agama Buddha, namun dalam pelaksanaan ritual memuja Tahon dan Balit masih melakukan pembunuhan yang mana dalam ajaran Buddha tidak diperbolehkan. Artinya ada nilai-nilai yang sangat mendalam yang 
terdapat dalam tradisi memuja Tahon dan Balit.

Tradisi memuja Tahon dan Balit sampai sekarang masih dipertahankan oleh masyarakat khususnya masyarakat Baru Murmas. Keberadaan tradisi memuja Tahon dan Balit yang masih berlangsung bukan berarti tidak mendapat tantangan karena kemajuan zaman dan perkembangan pendidikan. Kemajuan zaman dan berkembangnya pendidikan yang semakin maju merubah cara pandang generasi muda. Generasi muda yang menjadi tonggak keberlangsungan dari tradisi memuja Tahon dan Balit. Generasi muda yang menjadi harapan untuk melestarikan tradisi memuja Tahon dan Balit karena kemajuan zaman dan perkembangan pendidikan menentang keberadaan tradisi memuja Tahon dan Balit. Hal ini terbukti pada saat peneliti melakukan obsevasi pada tanggal 5 juli 2015 di Baru Murmas Desa Bentek Kecamatan Gangga Kabupaten Lombok Utara. Salah satu generasi muda menganggap pelaksanaan tradisi memuja Tahon dan Balit merupakan wujud menyembah kepada iblis, bukan sebagai penghormatan kepada leluhur.

Melihat kasus di atas dapat dikatakan bahwa makna dan nilai-nilai yang terkandung dalam tradisi memuja Tahon dan Balit kurang dipahami oleh generasi muda. Banyak faktor penyebab kurangnya pemahaman generasi muda tentang makna dan nilai-nilai yang terkandung dalam tradisi memuja Tahon dan Balit. Kurangnya bahkan tidak ada sama sekali sumber bacaan (karya ilmiah) tentang asalusul tradisi memuja Tahon dan Balit. Terkait asal-usul tradisi memuja Tahon dan Balit masih banyak yang belum mengetahui, karena anak muda yang menjadi generiasi penerus hanya dapat informasi sebatas lisan. Hal ini dikarenakan hanya orang tua tertentu yang mengetahui. Sementara orang tua yang menjadi sumber informasi semakin lama semakin berkurang. Bagi generasi muda pelaksanaan memuja Tahon dan Balit hanya sebagai kewajiban kepada leluhur tanpa mengetahui makna dan nilai-nilai yang terkandung dalam tradisi memuja Tahon dan Balit. Tanpa adanya pemahaman yang mendalam terhadap makna dan nilai-nilai tradisi memuja Tahon dan Balit menyebabkan lunturnya suatu kepercayaan. Jika kepercayaan terhadap tradisi sudah mulai luntur maka dalam pelaksanaannya akan berkurang. Terlihat setiap tahunnya terjadinya penurunan masyarakat yang hadir dalam mengikuti pelaksanaan tradisi memuja Tahon dan Balit.

Berdasarkan permasalahan yang dipaparkan sebelumnya serta kekhawatiran peneliti terhadap kebelangsungan tradisi memuja Tahon dan Balit, sehingga peneliti 
menganggap perlu dan layak untuk mengangkat tradisi memuja Tahon dan Balit di Dusun Baru Murmas Desa Bentek Kecamatan Gangga Kabupaten Lombok Utara sebagai objek penelitian dengan judul "Makna Tradisi memuja Tahon dan Balit Bagi Umat Buddha Dusun Baru Murmas Desa Bentek Kecamatan Gangga Kabupaten Lombok Utara”.

Berdasarkan uraian yang telah disampaikan dalam latar belakang, identifikasi dan pembatasan masalah mengenai tradisi memuja Tahon dan Balit yang masih tetap dilaksanakan oleh masyarakat Dusun Baru Murmas Desa Bentek Kecamatan Gangga Kabupaten Lombok Utara, maka peneliti merumuskan masalah sebagai berikut: apa makna yang terkandung dalam tradisi memuja Tahon dan Balit yang dilaksanakan oleh masyarakat Dusun Baru Murmas Desa Bentek Kecamatan Gangga Kabupaten Lombok Utara?, Nilai-nilai apa saja yang terkandung dalam tradisi memuja Tahon dan Balit yang dilaksanakan oleh masyarakat Dusun Baru Murmas Desa Bentek Kecamatan Ganggga Kabupaten Lombok Utara?. Tujuan dari penelitian ini adalah: mendeskripsikan makna yang terkandung dalam tradisi memuja Tahon dan Balit yang dilaksanakan oleh masyarakat Baru Murmas Desa Bentek Kecamatan Gangga Kabupaten Lombok Utara, dan mendeskripsikan nilai-nilai yang terdapat dalam tradisi memuja Tahon dan Balit yang dilaksanakan oleh masyarakat Baru Murmas Desa Bentek Kecamatan Gangga Kabupaten Lombok Utara.

\section{Tradisi}

Tradisi adalah adat kebiasaan turun temurun (dari nenek moyang) yang masih dijalankan dalam masyarakat, penilaian atau anggapan bahwa cara-cara yang telah ada merupakan yang paling baik dan benar (Tim 2014:1483). Hal yang paling mendasar dari tradisi adalah adanya informasi yang diteruskan dari generasi ke generasi baik scara tertulis maupun lisan, karena tanpa adanya ini, suatu tradisi dapat punah (Novianti dkk 2014: 7). Hasafi dalam Hakim (2013: 29) mendefinisikan bahwa tradisi merupakan segala warisan masa lampau yang pada masa kita dan masuk dalam kebudayaan yang sekarang. Menurut Hanafi bahwa tradisi itu tidak hanya peninggalan sejarah, tetapi juga merupakan persoalan zaman sekarang dengan berbagai tingkatannya.

\section{Ritual}

Ritual merupakan tata cara dalam upacara atau suatu perbuatan keramat yang dilakukan oleh sekelompok umat beragama. Yang ditandai dengan adanya berbagai macam unsur dan komponen, yaitu adanya waktu, tempat-tempat dimana upacara dilakukan, alat-alat dalam upacara, 
serta orang-orang yang menjalankan upacara (Koentjaraningrat 1985: 56).

Pada dasarnya ritual adalah rangkaian kata, tindakan pemeluk agama dengan menggunakan benda-benda, peralatan dan perlengkapan tertentu, ditempat tertentu dan memakai pakaian tertentu pula (Suprayogo 2001: 41). Ritual atau ritus dilakukan dengan tujuan untuk mendapatkan berkah atau rezeki yang banyak dari suatu pekerjaan. Seperti upacra menolak bahaya dan upacara karena perubahan atau siklus dalam kehidupan manusia seperti kelahiran, pernikahan dan kematian (Agus 2007: 95).

\section{Interaksi Simbolik}

Mempelajari interaksi sosial digunakan pendekatan tertentu, yang dikenal dengan nama interaksionist prespektive. Di antara berbagai pendekatan yang digunakan untuk mempelajari interaksi sosial, dijumpai pendekatan yang dikenal dengan nama interaksionosme simbolik (symbolic interactionism). Pendekatan ini bersumber pada pemikiran Mead. Dari kata interaksionisme sudah nampak bahwa sasaran pendekatan ini ialah interaksi sosial; kata simbolik mengacu pada penggunaan simbol-simbol dalam interaksi Douglas (Sunarto 2004: 35).

Interaksionis simbolik telah diperhalus untuk dijadikan salah satu pendekatan sosiologis oleh Blumer dan Mead, yang berpandangan bahwa manusia adalah individu yang berpikir, berperasaan, memberikan pengertian pada setiap keadaan, yang melahirkan reaksi dan interpretasi kepada setiap rangsangan yang dihadapi. Kejadian tersebut dilakukan melalui interpretasi simbol-simbol atau komunikasi bermakna yang dilakukan melalui gerak, bahasa, rasa simpati, empati, dan melahirkan tingkah laku lainnya yang menunjukan reaksi atau respon terhadap rangsangan-rangsangan yang datang kepada dirinya Bluner dan Mead (Salim 2008: 11). Pendekatan interaksionisme simbolik merupakan salah suatu pendekatan yang mengarah kepada interaksi yang menggunakan simbolsimbol dalam berkomunikasi, baik itu melalui gerak, bahasa dan simpati, sehingga akan muncul suatu respon terhadap rangsangan yang datang dan membuat manusia melakukan reaksi atau tindakan terhadap rangsangan tersebut. Dalam melakukan suatu interaksi, maka gerak, bahasa, dan rasa simpati sangat menentukan, apalagi berinteraksi dalam masyarakat yang berbeda suku dan kebudayaan. Modal utama dalam melakukan interaksi dalam masyarakat multi etnik adalah saling memahami kebiasaan ataupun kebudayaan dari orang lain, sehingga kesalah-pahaman yang nantinya akan menimbulkan konflik dapat tertekan. 


\section{METODE}

Penelitian ini dilakukan untuk memberikan gambaran mengenai kehidupan religi masyarakat Baru Murmas melalui salah satu komponen religinya yaitu tradisi memuja tahon dan balit. Penelitian ini menggunakan pendekatan studi kualitatif atau penelitian naturalistik.

Penelitian ini dilaksanakan di Dusun Baru Murmas Desa Bentek Kecamatan Gangga Kabupaten Lombok Utara. Alasan memilih tempat ini sebagai tempat penelitian karena di Baru Murmas Desa Bentek Kecamatan Gangga Kabupaten Lombok Utara masih melaksanakan tradisi memuja Tahon dan Balit.

Subjek dari penelitian ini adalah pemangku adat dan orang-orang yang mengetahui secara mendalam tentang tradisi memuja Tahon dan Balit. Sedangkan objek dari penelitian adalah pelaksanaan tradisi memuja Tahon danBbalit yang dilaksanakan oleh masyarakat Baru Murmas Desa Bentek Kecamatan Gangga Kabupaten Lombok Utara.

Teknik pengumpulan data adalah suatu cara untuk mengumpulkan keterangan-keterangan dalam suatu penelitian. Peneliti memilih tiga teknik pengumpulan data dalam penelitian ini. Ketiga teknik tersebut adalah observasi, wawancara dan dokumentasi.
Analisis data menurut Bogdan dan Biklen (Moleong 2013: 248) adalah upaya yang dilakukan dengan jalan bekerja dengan data, mengorganisasikan data, memilah-milahnya menjadi satuan yang dapat dikelola, mensintesiskannya, mencari dan menemukan pola, menemukan apa yang penting dan apa yang dipelajari, dan memutuskan apa yang dapat diceritakan kepada orang lain. Sementara itu Patton (Moleong 2013: 280) analisis data adalah proses mengatur urutan data, mengorganisasikannya ke dalam suatu pola, kategori, dan satuan uraian dasar.

\section{HASIL DAN PEMBAHASAN}

\section{Asal-Usul Tradisi Memuja Tahon dan Balit}

Dari paparan data yang diperoleh bahwa tradisi memuja Tahon dan Balit sudah ada sejak nenek moyang masyarakat Baru Murmas hidup dan tinggal di Dusun Baru Murmas. Seperti yang disampaikan oleh Bapak Budiartono selaku Mangku Tunang Tekang bahwa tradisi memuja Tahon dan Balit sudah ada sebelum mereka lahir, yang diwariskan oleh nenek moyang mereka secara turun temurun. Selain itu Bapak Sonia selaku pemangku Penghulu mengatakan hal yang sama bahwa tradisi memuja Tahon dan Balit sudah ada sebelum mereka lahir. Ada juga keterangan dari pemangku Pesalin bahwa tradisi memuja Tahon dan Balit berawal 


\section{Sabbhata Yatra}

Jurnal Pariwisata dan Budaya

Volume 1 Nomor 1 Juli 2020

dari nenek moyang masyarakat yang melaksanakan menggending. Adanya menggending terjadinya tradisi memuja Tahon dan Balit. Hal ini senada dengan pendapat Funk dan Wagnalls (Muhaimin 2001: 11) tentang istilah tradisi di maknai sebagai pengetahuan, doktrin, kebiasaan, praktek dan lain-lain yang dipahami sebagai pengatahuan yang telah diwariskan secara turun-temurun termasuk cara penyampaian doktrin dan praktek tersebut. Tradisi memuja Tahon dan Balit merupakan keyakinan masyarakat Baru Murmas sebelum mayarakat mengenal agama Buddha.

Tradisi memuja Tahon dan Balit adalah suatu tradisi masyarakat Baru Murmas yang sampai saat ini masih terus dipertahankan. Masyarakat Baru Murmas meyakini jika melaksanakan tradisi memuja Tahon dan Balit maka akan diberikan keselamatan, ketentraman, terhindar dari penyakit, dari bencana dan kemudahan dalam mencari rezeki. Tradisi memuja Tahon dan Balit sering dikaitakan dengan permohonan dan ucapan rasa syukur kepada Sanghyang Sidha Betera yang merupakan leluhur masyarakat Baru Murmas. Tradisi memuja Tahon dan Balit merupakan ungkapan penghayatan keyakinan asli masyarakat Baru Murmas.

Tahapan-Tahapan Pelaksanaan Tradisi Memuja Tahon dan Balit

Berdasarkan hasil wawancara yang didapat peneliti bahwa ada beberapa persiapan atau tahapan yang harus dilakukan sebelum pelaksanaan tradisi memuja Tahon dan Balit. Seperti yang dikatakan para mangku bahwa tahapantahapan dalam pelaksanaan tradisi memuja Tahon dan Balit yaitu: gundem (pertemuan), tama menyapu (perbersihan tempat pemujaan), dan perayaan tradisi memuja Tahon dan Balit. Untuk perayaan terbagi menjadi tiga sebutan dimana hari pertama dinamakan tun gong (menurukan alat-alat gamelan dari rumah mangku). Hari kedua dinamakan merowah (mengundang keluarga yang telah meninggal untuk makan minum). Hari ketiga tama pawang (memasuki hutang adat).

Pada saat perayaan tradisi memuja Tahon dan Balit, terdapat hari yang pertama disebut tun gong, hari kedua merowah dan hari ketiga tama pawang. Tun gong merupakan proses menurunkan alat-alat gamelan yang digunakan sebagai pengiring selama tradisi berlangsung sampai selesai. Pada hari kedua dilaksankan ritual merowah. Merowah merupakan ritual untuk mengundang keluarga atau leluhur yang telah meninggal untuk pulang ke rumah menikmati makanan dan minuman yang sudah disediakan oleh keluarga yang masih 


\section{Sabbhata Yatra}

Jurnal Pariwisata dan Budaya

Volume 1 Nomor 1 Juli 2020

hidup. Pada hari kedua juga terdapat ritual tari untuk menyatukan benda pusaka dan sebagai sambutan untuk leluhur Murmas dan Sanghyang Sidha Betara. Sementara hari ketiga yaitu tama pawang. Tama pawang adalah proses memasuki hutang adat tempat pemujaan masyarakat. Pawang (hutang adat) merupakan tempat tinggal leluhur masyarakat Baru Murmas yaitu Sanghyang Sidha Betara. Banyak ritual yang di lakukan pada saat berada di pawang diantaranya ritual menggerok dan belewasan (perang ketupat).

\section{Makna Tradisi Memuja Tahon dan Balit}

Berdasarkan data hasil temuan peneliti menunjukan bahwa tradisi memuja Tahon dan Balit sangat berpengaruh dalam kehidupan masyarakat Baru Murmas. Masyarakat Baru Murmas meyakini apabila tradisi memuja Tahon dan Balit tidak dilaksanakan, akan terjadi berbagai macam musibah seperti wabah penyakit dan berbagai macam bentuk bencana yang lain. Makna tradisi memuja sebenarnya adalah untuk mengingat leluhur, untuk melestarikan kebudayaan yang telah dijalankan oleh nenek moyang masyarakat Baru Murmas, untuk mendapatkan rezeki, keselamatan dan terhindar dari musibah sebagaimana yang telah dikatakan oleh beberapa informan yang sudah diwawancarai peneliti.

Makna yang terdapat dalam tradisi memuja Tahon dan Balit dapat dipahami sebagai suatu cara untuk menjaga kehidupan yang seimbang dan selaras anatar manusia, alam dan leluhur dengan cara membersihkan memberikan penghormatan kepada leluhur yang mengjaga masyarakat dari segala penyakit, bencana dan musibah, serta sebagai ungkapan rasa syukur masyarakat kepada leluhur atas rezeki, keselamatan dan terhindar dari penyakit.

\section{Nilai-Nilai Yang Terkandung Dalam}

\section{Tradisi Memuja Tahon dan Balit}

Masyarakat Baru Murmas sangat memegang teduh tradisi memuja Tahon dan Balit. Tradisi memuja Tahon dan Balit merupakan suatu keyakinan sebelum masyarakat mengenal ajaran agama Buddha. Oleh karena masyarakat sangat kuat dalam tradisi. Keteguhan masyarakat Baru Murmas untuk mempertahankan tradisi memuja Tahon dan Balit tidak terlepas dari nilai-nilai yang terkandung dalam tradisi memuja Tahon dan Balit. Terkait denagn nilai-nilai yang terkandung dalam tradisi memuja Tahon dan Balit beberapa pemangku seperti pemangku Tunang Tekang, pemangku Penghulu dan pemangku Pesalin serta Bapak Arya mengatakan bahwa nilai-nilai yang terkandumg seperti: nilai gotong royong, nilai kerelaan untuk berdana, nilai persatuan, nilai musyawarah. Hal senada juga disampaikan Isyanti bahwa terdapat lima nilai yang terkandung dalam setiap 


\section{Sabbhata Yatra}

Jurnal Pariwisata dan Budaya

Volume 1 Nomor 1 Juli 2020

tradisi yaitu: nilai gotong royong, nilai kesatuan dan persatuan, nilai musyawarah, nilai pengendalian sosial dan nila kearifan lokal.

\section{Alasan Masyarakat Masih \\ Melaksanakan Tradisi Memuja Tahon dan Balit}

Masyarakat Baru Murmas masih sangat kuat untuk mempertahankan tradisi tradisi memuja Tahon dan Balit. Kuatnya masyarakat Baru Murmas mempertahakan tradisi memuja Tahon dan Balit tentunya ada alasan-alasan yang mendasari, sehingga masyarakat masih melaksanakan tradisi memuja Tahon dan Balit. Sebagaimana yang sudah diterangkan oleh pemangku Tunang Tekang, pemangku Penghulu dan pemangku Pesalin serta Bapak Arya, jika masyarakat tidak melaksanakan tradisi memuja Tahon dan Balit sangat berpengaruh terhadap kehidupan masyarakat. Masyarakat percaya bahwa ada suatu kekuatan yang mengatur alam kehidupan diluar kemapuan masyarakat Baru Murmas. Tradisi memuja Tahon dan Balit sudah ada jauh sebelum agama Buddha masuk ke Baru Murmas. Masyarakat percaya bahwa dengan melaksanakan tradisi memuja Tahon dan Balit akan terhindar dari musibah, penyakit, mendapatkan keselamatan, dan kemudahan dalam memperoleh rezeki.

Tradisi memuja Tahon dan Balit merupakan suatu tradisi yang dilaksanakan

oleh masyarakat dusun Baru Murmas. Tradisi memuja Tahon dan Balit dilaksanakan pada bulan April dan Agustus. Tradisi memuja Tahon dan Balit yang dilaksanakan oleh masyarakat di dusun Baru Murmas Desa Bentek Kecamatan Gangga Kabupaten Lombok Utara merupakan bentuk penerusan tradisi dari nenek moyang. Hal ini senada dengan pendapat Funk dan Wagnalls (Muhaimin 2001: 11) tentang istilah tradisi di maknai sebagai pengetahuan, doktrin, kebiasaan, praktek dan lain-lain yang dipahami sebagai pengatahuan yang telah diwariskan secara turun-temurun termasuk cara penyampaian doktrin dan praktek tersebut. Masyarakat Baru Murmas jauh sebelum mengenal agama, tradisi memuja Tahon dan Balit sangat kuat dalam kehidupan masyarakat. Karena tradisi memuja Tahon dan Balit merupakan keyakinan masyarakat sebelum mengenal agama khususnya agama Buddha.

Tahapan-tahapan pelaksanaan tradisi memuja Tahon dan Balit di dusun Baru Murmas meliputi Gundem, Tama Menyapu, Tun Gong, Merowah dan Tama Pawang. Tata cara pelaksanaan tradisi memuja Tahon dan Balit telah melalui proses yang dilakukan berdasarkan ketentuan dan perlengkapan yang sudah di sepakati, mulai dari hari, tanggal serta sesajen yang sudah disiapakan. Sesajen yang ada dalam tradisi memuja Tahon dan 
Balit seperti: lekok buak, pesat menisan, ayam panggang, air, tuak, jajan pasar, ketupat, belayak, pisang, kacang-kacangan dan buah-buahan.

Tradisi memuja Tahon dan Balit mempunya makna yang mendalam bagi masyarakat dusun Baru Murmas. Makna tradisi memuja Tahon dan Balit sebenarnya adalah untuk mengingat leluhur, menjaga kehidupan yang seimbang dan selaras anatar manusia, alam dan leluhur dengan cara membersihkan memberikan penghormatan kepada leluhur yang mengjaga masyarakat dari segala penyakit, bencana dan musibah, serta sebagai ungkapan rasa syukur masyarakat kepada leluhur atas rezeki, keselamatan dan terhindar dari penyakit.

Tradisi memuja Tahon dan Balit juga memuat nilai-nilai yang sangat lekat dengan kehidupan masyarakat dusun Baru Murmas. Nilai-nilai tersebut diantaranya gotong royong, persatuan dan kesatuan, musyawarah, pengendalian sosial, dan kearifan lokal. Selain nilai-nilai tersebut terdapat nilai-nilai ajaran Buddha yang terkandung dalam tradisi memuja Tahon dan Balit. Nilai-nilai tersebut seperti penerusan tradisi keluarga dan kerelaan untuk berdana. Penerusan tradisi keluarga merupakan salah satu kewajiban anak kepada orang tua seperti yang dijelakasn dalam Sigalovada sutta. Oleh karena itu melaksanakan dan menjaga tradisi memuja
Tahon dan Balit artinya masyarakat dusun Baru Murmas yang keseluruhannya umat Buddha telah menjalankan nilai-nilai ajaran Buddha yaitu kewajiban sebagai seorang anak. Kerelaan untuk berdana merupakan perbuatan baik yang dilakukan oleh masyarakat dusun Baru Murmas yaitu dengan memberi orang yang membutukan baik berupa materi maupun non materi. Dana yang masyarakat berikan pada saat tradisi memuja Tahon dan Balit seperti beras, kelapa, gula dan kayu bakar serta tenaga.

Tradisi memuja Tahon dan Balit masih sangat terjaga keradaannya. Masyarakat dusun Baru Murmas masih sangat teguh dan kuat menjaga keberlangsungan dari tradisi memuja Tahon dan Balit. Ada alasan-alasan yang membuat masyarakat masih menjaga kelestarian dari tradisi memuja Tahon dan Balit. Alasan-alasan tersebut diantaranya jika tidak melaksanakan tradisi tersebut sangat berpengaruh terhadap kehidupan masyarakat, akan menimbulkan bencana, terserang penyakit. Dengan menjaga dan melaksanakan tradisi tersebut masyarakat akan terhindar dari bencana, musibah, penyakit dan mendapatkan kemudahan dalam rezeki.

\section{PENUTUP}

Berdasarkan hasil penelitian dengan pembahasan memlalui obsevasi, 
wawancara dan dokumentasi mengenai Makna Tradisi Memuja Tahon dan Balit Bagi Umat Buddha Dusun Baru Murmas Desa Bentek Kecamatan Gangga Kabupaten Lombok Utara peneliti dapat memberikan kesimpulan berdasarkan analisa data dan pembahasan sebagai berikut:

1. Makna tradisi memuja Tahon dan Balit adalah untuk mengingat leluhur, menjaga kehidupan yang seimbang dan selaras antar manusia, alam dan leluhur dengan cara membersihkan memberikan penghormatan kepada leluhur yang menjaga masyarakat dari segala penyakit, bencana dan musibah, serta sebagai ungkapan rasa syukur masyarakat kepada leluhur atas rezeki, keselamatan dan terhindar dari penyakit.

2. Tradisi memuja Tahon dan Balit memuat nilai-nilai yang sangat lekat dengan kehidupan masyarakat dusun Baru Murmas. Nilai-nilai tersebut diantaranya gotong royong, persatuan dan kesatuan, musyawarah, pengendalian sosial, dan kearifan lokal. Selain nilai-nilai diatas terdapat nilainilai ajaran Buddha yang terkandung dalam tradisi memuja Tahon dan Balit. Nilai-nilai itu seperti penerusan tradisi keluarga dan kerelaan untuk berdana.

\section{DAFTAR PUSTAKA}

Agus, Bustanuddin. (2007). Agama Dalam Kehidupan Manusia. Jakarta. Raja Grafindo Persada.

Andyani, Natalia Tri. (2013). Skripsi. Eksistensi Tradisi Saparan Pada Masyarakat Desa Sumberejo Kecamatan Ngablak Kabupaten Magelang. Semarang. Universitas Negeri semarang.

Burhan, Bungin (ed). (2007). Metodolgi

Penelitian Kualitatif Aktualisasi Metodologis ke Arah Ragam Varian Kontemporer. Surabaya. Rajawali Pers.

Fahroni. (2009). Intreksi Sosial Mahasiswa Asing Studi Tentang Mahasiswa Petani dalam Berinteraksi Dengan Warga Sekitar di dusun Karang Bendo, Banguntapan, Bantul.

Hakim, Muh Nur (2013). Islam

Tradisional dan Reformasi

Pragmatisme (Agama dalam

Pemikiran Hasan Hanafi). Malang.

Bayu Media Publishing.

Herdiyansyah, Haris (2010). Metode Penelitian Kualitatif Untuk IlmuIlmu Sosial. Jakarta. Salemba Humanika.

Isyanti. (2007). Tradisi Merti Bumi Sautu Refleksi Masyarakat Agraris. Jantra. Vulome II. Nomor 3. Hlm 1-103. 
Jones, Rip. (2003). Pengantar Teori-Teori Sosial Dari Teori Fungsional Hingga Post-Modernisme. Jakarta. Buku Obor.

Koentjaraningrat. (1985). Beberapa Pokok Antropologi Sosial. Jakarata. Dian Rakyat.

(1974). Kebudayaan, Mentalitet, dan Pembangunan. Jakarta. Gramedia.

Maran, Rafael Raga (2000). Manusian dan Kebudayaan Dalam Perspektik Ilmu Budaya Dasar. Jakarta. Rineka Cipta.

Walshe. Maurice. (2009). KhotbahKhotbah Panjang Sang Buddha Digha Nikaya. Jakarta. Dhamma Citta Press.

Moleong. Lexy J, (2013). Metodologi Penelitian Kualitatif Edisi Revisi. Bandung. Rosda

Muhaimin AG. (2001). Islam Dalam Bingkai Budaya Lokal: potret Dari Cerebon, Terj. Suganda. Ciputat. PT Logos Wacana Ilmu.

Mukti, Krishnanda Wijaya (2003). Wacana Buddha-Dhamma. Jakarta. Yayasan Dharma Pembangunan dan Sangha Agung Indonesia.

Narbuko, Cholid \& Achmadi, Abu. (2013). Metodologi Penelitian Memberi Bekal Teoritis Pada Mahasiswa Tentang Metodologi Penelitian
Serta Diharapkan Dapat Melaksanakan Penelitian Dengan Langkah-Langkah Yang Benar. Jakarta. Bumi Aksara.

Nasution, M.A. (1996). Metode penelitian Naturalistik Kualitatif. Bandung. Transito

Novianti dkk. (2014). Tradisi Mitoni Dalam Pandangan Agama Buddha Penelitian Lapangan di Dusun Sodong Desa Gelangkulon Kecamatan Sampung Kabupaten Ponorogo. Wonogiri. STABN Raden Wijaya.

Sztompka, Piotr. (2007). Sosiologi Perubahan Sosial. Jakarta. Parsada.

Prastowo, Andi (2011). Metode Penelitian Kualitatif Dalam Perspektif Rancangan Penelitian. Jogjakarta. AR-RUZZMEDIA.

Raho, Bernard. (2007). Teori Sosiologi Modern. Jakarta. Prestasi Pustaka.

Salim, Agus. (2008). Pengentar Sosiologi Mikro. Yogyakarta. Pustaka Pelajar.

Sobur, Alex, (2001). Analisis Teks Media, Bandung: Remaja Rosdakarya (2003). Semiotika Komunikasi, Bandung: Remaja Rosdakarya

Soekamto, Sujono. (2001). Sosiologi Suatu Pengantar. Jakarta. Raja Grafindo Persada. 
Jurnal Pariwisata dan Budaya

Volume 1 Nomor 1 Juli 2020

Sunarto, Kamanto. (2004). Pengantar Sosiologi Edisi Revisi. Jakarta. Lembaga Penerbit Fakultas Ekonomi Universitas Indonesia.

Suprayogo, Imam. (2001). Metodologi Penelitian Sosial-Agama. Bandung Remaja Rosda Karya.

Surtman, dkk. (2010). Ilmu Sosial dan Budaya Dasar. Malang. Intimedia.

Syafruddin. (2011). Pola Komunikasi Antar Budaya Dalam Interaksisosial Etnis Karo dan Etnis Minang di Kecamatan Kabanjahe Kabupaten Karo. Jurnal Ilmu Sosial Fakultas Isipol UMA. Volume 4. Hlm 87.

Tasmuji, dkk (2011). Ilmu Alamiah Dasar, Ilmu Sosial Dasar, Ilmu Budaya Dasar. Surabaya. IAIN Suna Ampel Press.

Tim. (2014) Kamus Besar Bahasa Indonesia Pusat Bahasa
Depertemen Pendidikan Nasianol. Jakarta. PT Gramedia Pustaka Utama.

Tim. (2013). Dhammapada Syair Kebenaran. Jakarta. Ehipassiko Foundation.

Tjiptadi, Bambang. (1984).Tata Bahasa Indonesia. Cetakan II. Jakarta: Yudistira.

Wowor, Cornelis. (1991). Padangan Sosial Agama Buddha. Jakarta. Nitra Kencana Buana.

Yuniati, dkk. (2015). Komunikasi Ritual Dalam Traddisi Perang Topat Di Taman Lingsar Kabupaten Lombok Barat. Widya Sandhi. Volume 6. Nomor 1. Hlm 1-14. 